\title{
Detection of Legionellae pneumophila in Waters by Culture and Polymerase Chain Reaction
}

\author{
Omar Bashir Ahmed \\ Department of Environmental and Health Research, the Custodian of the Two Holy Mosques Institute for Hajj and \\ Umrah Research, Umm Al-Qura University, Makkah, Saudi Arabia \\ Email: abuaglah1@hotmail.com
}

How to cite this paper: Ahmed, O.B. (2020) Detection of Legionellae pneumophila in Waters by Culture and Polymerase Chain Reaction. Advances in Microbiology, 10, 456-462.

https://doi.org/10.4236/aim.2020.109034

Received: July 16, 2020

Accepted: September 21, 2020

Published: September 24, 2020

Copyright $\odot 2020$ by author(s) and Scientific Research Publishing Inc. This work is licensed under the Creative Commons Attribution International License (CC BY 4.0).

http://creativecommons.org/licenses/by/4.0/

(c) (i) Open Access

\begin{abstract}
Legionella pneumophila (L. pneumophila) is the most common causative agents for all outbreaks of Legionnaires' disease. Prevention and control of Legionellosis requires surveying and monitoring of Legionella in the environment using conventional and modern technologies. The present study aims to compare detection of $L$. pneumophila in water samples using both culture and PCR techniques. A pre-enriched contaminated water sample was split into 13 subsamples. Culture and PCR tests were done from the subsamples after different intervals. The results showed a positive PCR result for $L$. pneumophila after $8 \mathrm{~h}$ of incubation. Also, L. pneumophila was detected by culture on non-selective BCYNE agar and selective GPVC agar after 5 and 6 days of incubation respectively. There was no significant difference between the non-selective BCYE- and the selective GVPC method. The PCR procedure was found more sensitive and differed significantly from the conventional selective GVPC method in isolation of $L$. pneumophila from water samples. It was concluded that pre-enrichment incubation allows the detection of $L$. pneumophila by PCR within a maximum of $12 \mathrm{~h}$ from the collection of water samples.
\end{abstract}

\section{Keywords}

Legionella pneumophila, PCR, BCYNE Agar, GPVC Agar, Water Samples

\section{Introduction}

Legionellae is a Gram-negative, aerobic, non-spore-forming, encapsulated bacillus. The genus Legionella comprises approximately 53 species. They are ubiquitous in natural fresh water environments such as lakes and streams. They pose a serious health risk into building water systems, and man-made aqueous environments which are rich with aerosolised water droplets [1]. L. pneumophi- 
la is the causative agents for $90 \%$ of all outbreaks of Legionnaires' disease and Pontiac fever [2]. In addition, at least 20 other species of Legionella have been associated with human infections [3]. Transmission may be carried out from whirlpool spas, hot and cooling towers, air conditioning, and humidifiers. Prevention and control of Legionellosis requires surveying and monitoring of Legionella in the environment using conventional and modern technologies. Bacterial growth in the aqueous environment is sometimes exposed to stresses due to unfavorable conditions, so they adapt to such conditions by entering a temporarily non-cultivable state. In this state, they could only be grown into embryonated eggs or into amoeba (such as Acanthamoeba castellanii). Conventional methods include direct culture which is considered the "gold standard" and the classical method for detection of Legionella species using either selective or non-selective media such as, glycine-polymyxin B-vancomycin-cycloheximide (GPVC) agar or buffered-charcoal-yeast extract (BCYE) agar [4] [5]. However, the culture method is time-consuming because $L$. pneumophila is fastidious and too slow to grow, hence it is difficult to detect viable cells of $L$. pneumophila in routine culture methods, also the contaminants and impurities may interfere and hinder the Legionella growth [6] [7] [8] [9]. The rapid detection of L. pneumophila is essential to regulate the surveillance and control of $L$. pneumophila in supplied water. The application of PCR for the detection of $L$. peumophila DNA is useful for the early monitoring and controlling the organisms in water samples. This technique is cost-effective and reliable and has been described as useful tools for the detection of $L$. pneumophila in clinical and environmental samples. PCR has been considered a very promising tool for the detection of $L$. pneumophila DNA [10] [11]. Despite the advantages of conventional PCR, presence of inhibitors in water samples may produce false-negative results. In addition, conventional PCR is a qualitative, not quantitative method. To avoid such limitations, the chance of detecting L. pneumophila can be greater when using a pre-enrichment step prior to plating onto solid selective media or detection by PCR [12]. The present study aims to compare detection of $L$. pneumophila in pre-enrichment water samples using both culture and PCR techniques.

\section{Materials and Methods}

The study was carried out during period (January to June 2019) in the microbiology laboratory at the department of Environmental and Health Research, the Custodian of the Two Holy Mosques Institute for Hajj and Umrah, Umm Al-Qura University, Makkah, Saudi Arabia. Detection of the organism was undertaken after inoculation of water samples with L. pneumophila (ATCC 33152) by culture and PCR methods. Firstly, before inoculation, water sample was sterilized for $15 \mathrm{~min}$ at $121^{\circ} \mathrm{C}$ to eliminate any bacteria potentially present in the water. Aliquots of $30 \mathrm{ml}$ of an overnight culture on Buffered yeast extract broth (BYEB) medium of $L$. pneumophila isolates, containing $1 \times 10^{8} \mathrm{CFU} \mathrm{ml}^{-1}$, was prepared. Next, the $30 \mathrm{ml}$ of suspension was added to $1270 \mathrm{ml}$ of the water sample to obtain a contaminated sample. Then, $130 \mathrm{ml}$ of the sample was transferred 
to a bottle, consisting of $1170 \mathrm{ml}$ media (BYEB). The method was conducted in triplicates. The water sample was split into 13 subsamples (each subsample was of $100 \mathrm{ml})$. An uninoculated heat-treated water sample (100 ml) was used as a negative control. While incubation at $38^{\circ} \mathrm{C}$ for 10 days, culture and PCR tests were done from each subsample, after $0,2,4,8,12,24,48$ hours, and then after 3, 4, 5, 6,7 , and 10 days. From each water subsample, the $100 \mathrm{ml}$ was concentrated by filtration using 47-mm-diameter polycarbonate membranes. In each sample, filter was placed in $10 \mathrm{ml}$ of original water sample in a tube. Each tube was then vortexed for a few minutes, and the ten $\mathrm{ml}$ of solution was then concentrated to $1 \mathrm{ml}$ by centrifugation at $10,000 \mathrm{~g}$ for $1 \mathrm{~min}$, hence to get high number of organisms. A 0.1-ml volume of the concentrated sample was spread plated onto on non-selective BCYE agar and selective GPVC media, and incubated at $38^{\circ} \mathrm{C}$ with $3 \% \mathrm{CO}_{2}$. All media were examined initially for the presence of Legionella bacteria. For PCR, firstly DNA was extracted by boiling method. Briefly, after concentration, $50 \mu \mathrm{L}$ of water sample was placed into a tube, then subjected to boiling at $100^{\circ} \mathrm{C}$ for five minutes. The sample was centrifuged at $3000 \mathrm{~g}$ for 10 minutes. The DNA-containing upper aqueous phase was recovered by centrifugation for 20 min, and genomic DNA was precipitated by ethanol [13]. The quantity and purity of extracted DNA were checked by spectrophotometry at $260 \mathrm{~nm}$ and the A260/A280 ratio. PCR was done by taking $50 \mu$ of PCR mixture. The mixture contained $5 \mu \mathrm{l}$ of DNA template, $1 \mu \mathrm{l}(100 \mathrm{pmol})$ of each primer, a $25 \mu \mathrm{l}$ of Taq PCR Master Mix polymerase (Qiagen, USA), and RNase free distilled water. The primers used in this study were obtained from IDT Integrated DNA technologies (IDT, Belgium). Mastercycler PCR machine (Eppendorf, Germany) was used for PCR reaction. The primers LEG 225 (5' AAGATTAGCCTGCGTCCGAT-3') and LEG 858 (5' GTCAACTTATCGCGTTTGCT-3') were used to amplify a $650 \mathrm{bp}$ fragment of the 16SrRNA gene of the bacterium according to Hsu et al., [14]. The cycling conditions were as follows: Denaturation (at $94^{\circ} \mathrm{C}$ for $5 \mathrm{~min}$ ), 35 cycles of denaturation (at $95^{\circ} \mathrm{C}$ for $30 \mathrm{~s}$ ), annealing (at $64^{\circ} \mathrm{C}$ for $30 \mathrm{~s}$ ), extension (at $74^{\circ} \mathrm{C}$ for $20 \mathrm{~s}$ ), and then 1 final extension cycle (at $72^{\circ} \mathrm{C}$ for $5 \mathrm{~min}$ ). The PCR products were viewed by gel electrophoresis $(1.5 \%)$ and under UVP BioDoct It Imaging System after staining with ethidium bromide $(2 \mathrm{mg} / \mathrm{ml})$. Statistical analyses were carried out using the IBM SPSS version 23 software program $\left(\mathrm{IBM}^{\circ}\right.$ SPSS ${ }^{\circledR}$ Statistics, NY, USA). The culturing on the selective GPVC media was considered as "gold standard" and was assessed in McNemar's test.

\section{Results and Discussion}

The routine tests for the environmental monitoring of Legionella should be rapid and accurate and must be able to detect all living bacterial cells even those cannot be cultured. The present study aimed to compare detection of $L$. pneumophila in water samples using both culture and PCR techniques. The results showed that $L$. pneumophila was detected by PCR after $8 \mathrm{~h}$ of incubation (Figure 1). Table 1 shows that 10 of the samples (76.9\%) showed positive results by PCR test while Table 2 shows sensitivity of $77 \%$. Likewise, in many studies, 
Legionella strains including L. pneumophila was isolated in the water samples [15] [16] [17].

Table 1 also shows $L$. pneumophila was detected by culture on non-selective BCYNE agar after 5 days of incubation. The total number of the positive samples by culturing on non-selective BCYNE agar was 4 (30.7\%) with sensitivity of (30.7) as shown in Table 1. Also L. pneumophila was detected by culture on selective GPVC agar after 6 days of incubation. The control sample (uninoculated heat-treated water) was found to be negative. Edagawa et al., reported that $20.0 \%$ water samples from buildings were positive by culture, qualitative PCR or both methods [18]. With respect to the positive Legionella cultures, there was no significant difference between the non-selective BCYE- and the selective GVPC media ( $p$-value $=0.137$ ), however, the PCR method differs significantly from the conventional selective GVPC media $(p$-value $=0.008)($ Table 2$)$. Table 2 also shows that, the use of non-selective BCYE- method in the isolation of $L$. pneumophila from water samples was less sensitive (30.7\%) than PCR procedure (77\%), and that was consistent with previous observations [19]. There was even, a study in which the culture method showed negative growth in all samples [20]. The lowest colony counts detected by the non-selective BCYE- and the selective GVPC media were $5.2 \times 10^{2} \mathrm{cfu} / \mathrm{ml}$ (after 5 days' incubation at $37 \mathrm{C}$ ) and $6.5 \times$ $10^{2} \mathrm{cfu} / \mathrm{ml}$ (after 6 days' incubation at $37 \mathrm{C}$ ) respectively. Many factors may explain the low sensitivity rate of detection $L$. pneumophila by culture in water samples, such as: the presence of viable but non-culturable cells, loss of viability of bacteria after collection, and low concentration of legionellae in the samples [21]. Similar observations were reported by other authors [22] [23] [24]. The reason for the significant discrepancy between PCR and culture results for Legionella in water samples is the greater positivity rates for PCR than culture [25].

Table 1. Detection of Legionella spp. in water subsamples by culture and PCR techniques.

\begin{tabular}{|c|c|c|c|c|}
\hline $\begin{array}{c}\text { Sub } \\
\text { sample }\end{array}$ & Time & $\begin{array}{c}\text { Non-selective } \\
\text { BCYNE agar } \mathrm{cfm} / \mathrm{ml}\end{array}$ & $\begin{array}{c}\text { Selective GPVC } \\
\text { agar } \mathrm{cfm} / \mathrm{ml}\end{array}$ & PCR \\
\hline 1 & 0 hours & 0 & 0 & -ve \\
\hline 2 & 2 hours & 0 & 0 & $-\mathrm{ve}$ \\
\hline 3 & 4 hours & 0 & 0 & -ve \\
\hline 4 & 8 hours & 0 & 0 & +ve (faint) \\
\hline 5 & 12 hours & 0 & 0 & +ve \\
\hline 6 & 24 hours & 0 & 0 & $+v e$ \\
\hline 7 & 48 hours & 0 & 0 & $+v e$ \\
\hline 8 & 72 hours & 0 & 0 & +ve \\
\hline 9 & 4 days & 0 & 0 & + ve \\
\hline 10 & 5 days & $5.2 \times 10^{2}$ & 0 & $+\mathrm{ve}$ \\
\hline 11 & 6 days & $7.5 \times 10^{2}$ & $6.5 \times 10^{2}$ & + ve \\
\hline 12 & 7 days & $2.1 \times 10^{3}$ & $3.4 \times 10^{3}$ & +ve \\
\hline 13 & 10 days & $1.5 \times 10^{4}$ & $2.2 \times 10^{4}$ & $+v e$ \\
\hline Control & Everyday & 0 & 0 & $-\mathrm{ve}$ \\
\hline
\end{tabular}


Table 2. Comparison of pre-enrichment methods with BYEB medium for isolation of $L$. pneumophila from water samples.

\begin{tabular}{|c|c|c|c|c|c|c|}
\hline & & \multicolumn{2}{|c|}{ PCR } & \multicolumn{2}{|c|}{$\begin{array}{l}\text { Non-selective } \\
\text { BCYNE agar }\end{array}$} & \multirow[t]{2}{*}{ Total } \\
\hline & & + & - & + & - & \\
\hline \multirow[t]{2}{*}{ Selective GPVC agar } & + & 3 & 0 & 3 & 0 & 3 \\
\hline & - & 7 & 3 & 1 & 9 & 10 \\
\hline Total & & 10 & 3 & 4 & 9 & 13 \\
\hline$P$-value & & \multicolumn{2}{|c|}{0.008} & \multicolumn{2}{|c|}{0.137} & \\
\hline Sensitivity & & \multicolumn{2}{|c|}{$77 \%$} & \multicolumn{2}{|c|}{$30.7 \%$} & \\
\hline
\end{tabular}

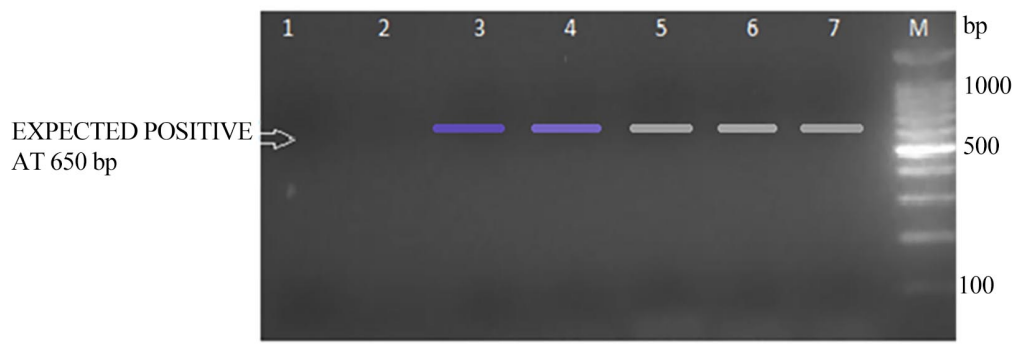

Figure 1. Lane 1; Negative control. Lane 2: negative LEG gene of L. pneumophila. Lanes 3, 4, 5, and 6: positive LEG gene of $L$. pneumophila (650 bp). Lane 7: Positive control positive. Lane M: 100-bp DNA ladder.

\section{Conclusion}

There was no significant difference between the non-selective BCYE- and the selective GVPC media, however, the PCR method differs significantly from the conventional selective GVPC media. The PCR method after pre-enrichment is rapid and simple for the detection of $L$. pneumophila in water samples.

\section{Conflicts of Interest}

The author declares no conflicts of interest regarding the publication of this paper.

\section{References}

[1] Fields, B.S., Benson, R.F. and Besser, R.E. (2002) Legionella and Legionnaires' Disease: 25 Years of Investigation. Clinical Microbiology Reviews, 15, 506-526. https://doi.org/10.1128/CMR.15.3.506-526.2002

[2] Fábio, R.S., Carvalho, Annette, S., Foronda, Vivian, H. and Pellizari. (2007) Detection of Legionella pneumophila in Water and Biofilm Samples by Culture and Molecular Methods from Man-Made Systems in São Paulo-Brazil. Journal of Microbiology, 38, 743-751. https://doi.org/10.1590/S1517-83822007000400029

[3] Conza, et al. (2013) Detection limits of Legionella pneumophila in Environmental Samples after Co-Culture with Acanthamoeba polyphaga. BMC Microbiology, 13, Article No. 49. https://doi.org/10.1186/1471-2180-13-49

[4] Bonetta, S., Bonetta, S., Ferretti, E., et al. (2010) Evaluation of Legionella pneumo- 
phila Contamination in Italian Hotel Water Systems by Quantitative Real-Time PCR and Culture Methods. Journal of Applied Microbiology, 108, 1576-1583. https://doi.org/10.1111/j.1365-2672.2009.04553.X

[5] Edelstein, P.H. (1981) Improved Semiselective Medium for Isolation of Legionella pneumophila from Contaminated Clinical and Environmental Specimens. Journal of Clinical Microbiology, 14, 298-303. https://doi.org/10.1128/JCM.14.3.298-303.1981

[6] Yáñez, M.A., Carrasco-Serrano, C., Barberá, V.M., Catalán, V.(2005) Quantitative Detection of Legionella pneumophila in Water Samples by Immunomagnetic Purification and Real-Time PCR Amplification of the $\operatorname{dot} A$ Gene. Applied and Environmental Microbiology, 71, 3433-3441. https://doi.org/10.1128/AEM.71.7.3433-3441.2005

[7] Conza, L., Casati, S., and Gaia, V. (2013) Detection Limits of Legionella pneumophila in Environmental Samples after Co-Culture with Acanthamoeba polyphaga. BMC Microbiology, 13, Article No. 49. https://doi.org/10.1186/1471-2180-13-49

[8] Delgado-Viscogliosi, P., Simonart, T., Parent, V., Marchand, G., Dobbelaere, M., Pierlot, E., Pierzo, V., Menard-Szczebara, F., Gaudard-Ferveur, E., Delabre, K., et al. (2005) Rapid Method for Enumeration of Viable Legionella pneumophila and Other Legionella spp. in Water. Applied and Environmental Microbiology, 71, 4086-4096. https://doi.org/10.1128/AEM.71.7.4086-4096.2005

[9] Alleron, L., Merlet, N., Lacombe, C. and Frere, J. (2008) Long-term Survival of Legionella pneumophila in the Viable but Nonculturable State after Monochloramine Treatment. Current Microbiology, 57, 497-502. https://doi.org/10.1007/s00284-008-9275-9

[10] Dimitriadi, D. and Velonakis, E. (2014) Detection of Legionella spp. from Domestic Water in the Prefecture of Arta, Greece. Journal of Pathogens, 2014, Article ID: 407385. https://doi.org/10.1155/2014/407385

[11] Leoni, E., Legnani, P.P., Bucci Sabattini, M.A. and Righi, F. (2001) Prevalence of Legionella spp. in Swimming Pool Environment. Water Research, 35, 3749-3753. https://doi.org/10.1016/S0043-1354(01)00075-6

[12] States, S.J., Wadowsky, R.M., Kuchta, J.M., Wolford, R.S., Conley, L.F. and Yee, R.B. (1990) Legionella in Drinking Water. In: McFeters, G.A., Ed., Drinking Water Microbiology: Progress and Recent Developments. Springer-Verlag, New York, 340-367. https://doi.org/10.1007/978-1-4612-4464-6 16

[13] Ahmed, O.B. and Dablool, A.S. (2017) Quality Improvement of DNA Extracted by Boiling Method in Gram Negative Bacteria. International Journal of Bioassays, 6, 5347-5349. https://doi.org/10.21746/ijbio.2017.04.004

[14] Hsu, B.M., Chen, C.H., Wan, M.T. and Cheng, H.W. (2006) Legionella Prevalence in Hot Spring Recreation Areas of Taiwan. Water Research, 40, 3267-3273. https://doi.org/10.1016/j.watres.2006.07.007

[15] Codony, F., Alvarez, J., Oliva, J.M., et al. (2002) Factors Promoting Colonization by Legionellae in Residential Water Distribution Systems: An Environmental Case-Control Survey. European Journal of Clinical Microbiology and Infectious Diseases, 21, 717-721. https://doi.org/10.1007/s10096-002-0789-y

[16] Pedro-Botet, M.L., Stout, J.E. and Yu, V.L. (2002) Legionnaires' Disease Contracted From Patient Homes: The Coming of the Third Plague? European Journal of Clinical Microbiology and Infectious Diseases, 21, 699-700. https://doi.org/10.1007/s10096-002-0813-2 
[17] Bates, M.N., Maas, E., Martin, T., Harte, D., Grubner, M. and Margolin, T. (2000) Investigation of the Prevalence of Legionella Species in Domestic Hot Water Systems. The New Zealand Medical Journal, 113, 218-220.

[18] Edagawa, A., Kimura, A., Doi, H. et al. (2008) Detection of Culturable and Nonculturable Legionella Species from Hot Water Systems of Public Buildings in Japan. Journal of Applied Microbiology, 105, 2104-2114. https://doi.org/10.1111/j.1365-2672.2008.03932.x

[19] Bartie, C., Venter, S.N. and Nel, L.H. (2003) Identification Methods for Legionella from Environmental Samples. Water Research, 37, 1362-1370. https://doi.org/10.1016/S0043-1354(02)00220-8

[20] Payment, P., Bérubé, A., Perreault, D., Armon, R. and Trubel, M. (1989) Concentration of Giardia lamblia Cysts, Legionella pneumophila, Clostridium perfringens, Human Enteric Viruses, and Coliphages from Large Volumes of Drinking Water, Using a Single Filtration. Canadian Journal of Microbiology, 35, 932-935. https://doi.org/10.1139/m89-154

[21] Díaz-Flores, Á, Montero, J.C., Castro, F.J., Alejandres, E.M., Bayón, C., et al. (2015) Comparing Methods of Determining Legionella spp. in Complex Water Matrices. BMC Microbiology, 15, Article No. 91. https://doi.org/10.1186/s12866-015-0423-7

[22] Catalan, V., Moreno, C., Dasi, M.A., Muñoz, C. and Apraiz, D. (1994) Nested polymerase Chain Reaction for Detection of Legionella pneumophila in Water. Research in Microbiology, 145, 603-610. https://doi.org/10.1016/0923-2508(94)90077-9

[23] Hussong, D., Colwell, R.R., O’Obrien, M., Weiss, E., Pearson, A.D., Wiever, R.M. and Burge, W.D. (1987) Viable Legionella pneumophila Not Detectable by Culture on Agar Media. Nature Biotechnology, 5, 947-950. https://doi.org/10.1038/nbt0987-947

[24] Gruas, C., Álvarez, I., Lara, C., et al. (2013) Identification of Legionella spp. in Environmental Water Samples by ScanVIT-Legionella ${ }^{\mathrm{TM}}$ Method in Spain. Indian Journal of Microbiology, 53, 142-148. https://doi.org/10.1007/s12088-013-0363-6

[25] Touron-Bodilis, A., Pugnard, C., Frenkiel-Lebossé, H. and Hallier-Soulier, S. (2011) Usefulness of Real-Time PCR as a Complementary Tool to the Monitoring of Legionella spp. and Legionella pneumophila by Culture in Industrial Cooling Systems. Journal of Applied Microbiology, 111, 499-510.

https://doi.org/10.1111/j.1365-2672.2011.05063.x 